\title{
PENGEMBANGAN SOFT SKILL TANGGAP BENCANA KEBAKARAN SEBAGAI UPAYA PREVENTIF BAGI SISWA SD
}

\author{
Dyah Puspita Indah Budi Sari Wulan ${ }^{1}$, Nurleila Jum'ati ${ }^{2}$, Risca Ayu Rachmania ${ }^{3}$, Nur Aini \\ Azizah $^{4}$, Mochamad Syahrul Gunawan ${ }^{5}$, Raihana $^{6}$, Okky Irfanto ${ }^{7}$ \\ ${ }_{1,2,3,4,5,6,7}$ Universitas Wijaya Putra \\ nurleila@uwp.ac.id
}

\begin{abstract}
Abstrak
Indonesia adalah salah satu negara yang rawan bencana, salah satu yang rentan menjadi korban bencana adalah anak-anak. Terdapat data kebakaran di lingkungan pendidikan di kota Surabaya Barat dan data potensi kebakaran di wilayah barat Surabaya. Dengan data-data tersebut maka mendorong diadakannya kegiatan pengabdian masyarakat berupa peningkatan soft skill terhadap mitigasi, kesiapsiagaan menghadapi bencana kebakaran. Pengembangan soft skill tanggap bencana kebakaran sebagai upaya preventif pada anak sejak dini dilakukan pada siswa SD AlKautsar Surabaya. Metode pelaksanaan pengabdian kepada masyarakat yang dilakukan adalah observasi, pretest, sosialisasi, pendampingan, membentuk komunitas fire fighter dan posttest. Berdasarkan nilai rata-rata pengetahuan yang didapatkan oleh siswa cukup tinggi setelah mengikuti program dibandingkan sebelumnya. Dengan mengikuti peningkatan soft skill, siswa mendapatkan pengetahuan dan penguatan pendidikan karakter, pengembangan literasi serta menumbuhkan self-efficacy siswa. Dengan selfefficacy, siswa memperoleh pengetahuan tersebut untuk diri sendiri dan dapat mengedukasi lingkungan sekitarnya. Diharapkan untuk keberlanjutan program dapat terbentuk komunitas yang diwadahi dalam sebuah ekstrakurikuler fire fighter yang melibatkan pihak : sekolah, orang tua siswa atau perwakilan komite sekolah dan siswa serta seluruh warga sekolah yang lain.
\end{abstract}

Kata Kunci : Pendidikan, Kebakaran, Soft Skill, Self-Efficacy

\begin{abstract}
Indonesia is one of the countries that are prone to disasters, one of the vulnerable victims of disasters is children. There is fire data in the educational environment in the city of West Surabaya and data on potential fires in the western region of Surabaya. With these data, it encourages the holding of community service activities in the form of improving soft skills towards mitigation, preparedness for fire disasters. The development of soft skills to respond to fire disasters as a preventive effort in children from an early age is carried out in students of AlKautsar Elementary School Surabaya. Methods of community service are observation, pretest, socialization, mentoring, forming a fire fighter community and posttest. Based on the average value of knowledge obtained by students is quite high after joining the program compared to before. By following the improvement of soft skills,
\end{abstract}


students gain knowledge and strengthen the education of character, literacy development as well as fostering self-efficacy students. With self-efficacy, students acquire such knowledge for themselves and can educate the surrounding environment. It is hoped that for the sustainability of the program can be formed a community that is accommodated in an extracurricular fire fighter involving parties: schools, parents of students or representatives of school committees and students and all other school residents.

Keywords: Education, Fire, Soft Skills, Self-Efficacy

\section{PENDAHULUAN}

Bencana adalah rangkaian peristiwa yang memberikan ancaman dan mengganggu kehidupan masyarakat, disebabkan oleh faktor alam, nonalam maupun faktor manusia sehingga menimbulkan korban jiwa, kerusakan lingkungan, kehilangan harta benda dan dampak psikologis (BNPB, 2021a). Berdasarkan UU No. 24 Tahun 2007 bencana dibedakan menjadi 3 yaitu : (1) Bencana alam adalah bencana yang terjadi akibat adanya peristiwa alam seperti gempa bumi, tsunami, gunung meletus, banjir, kekeringan, angin topan dan tanah longsor; (2) Bencana nonalam adalah bencana yang terjadi akibat peristiwa non alam seperti gagal teknologi, gagal modernisasi, epidemi dan wabah penyakit; dan (3) Bencana sosial adalah bencana yang terjadi akibat perilaku manusia meliputi konflik sosial antar kelompok atau antar komunitas masyarakat.

Berdasarkan Arnold dalam (BNPB, 2017), Indonesia merupakan salah satu negara yang memiliki tingkat kegempaan (bencana alam) 10 kali lipat lebih tinggi dibandingkan Amerika Serikat. Potensi bencana lainnya di Indonesia juga dipengaruhi oleh meningkatnya jumlah penduduk di Indonesia. Berdasarkan data (Badan Pusat Statistik, 2021), hingga september 2020 jumlah penduduk Indonesia meningkat sebesar 32,57 dengan jumlah penduduk total 270,2 juta jiwa. Tingginya pertumbuhan penduduk yang tidak diimbangi dengan kebijakan pembangunan ekonomi, sosial dan infrastruktur yang memadai dapat menimbulkan bencana nonalam dan bencana sosial lainnya, salah satunya adalah bencana kebakaran.

Kebakaran adalah situasi dimana bangunan seperti rumah, pemukiman, pabrik, pasar, gedung dan lainnya dilanda api sehingga menimbulkan korban dan/atau kerugian (BNPB, 2021a). Menurut Kepala Pusat Data, Informasi dan Komunikasi Kebencanaan Badan Nasional Penanggulangan Bencana (BNPB) Agus Wibowo dalam (Samodro, 2020) mengatakan bahwa sebanyak $31 \%$ korban bencana yang terjadi pada tahun 2020 adalah anak anak.

Dilansir dari beberapa laman, kebakaran terjadi di beberapa intitusi pendidikan di Surabaya.

Tabel 1. Data Kebakaran di Institusi Pendidikan di Surabaya

\begin{tabular}{|c|c|c|c|}
\hline Tahun & Jenjang & Institusi & Dampak \\
\hline 2017 & SD & $\begin{array}{l}\text { SDN } \\
\text { Kapasan } \\
3\end{array}$ & $\begin{array}{l}\text { Merusak } 2 \text { Kelas dan } 2 \text { ruang } \\
\text { praktikum, serta perangkat } \\
\text { komputer di sekolah }\end{array}$ \\
\hline \multirow{4}{*}{2018} & SMP & $\begin{array}{l}\text { SMPN } \\
21\end{array}$ & $\begin{array}{l}80 \text { unit komputer dan } 2 \text { server } \\
\text { komputer terbakar }\end{array}$ \\
\hline & SMP & $\begin{array}{l}\text { SMPN } \\
42\end{array}$ & $\begin{array}{l}\text { Satu ruangan gudang terbakar } \\
\text { dan } 1 \text { siswa cedera }\end{array}$ \\
\hline & \multirow[t]{2}{*}{ SMK } & $\begin{array}{l}\text { SMKN } \\
6\end{array}$ & $\begin{array}{l}\text { Sebanyak } 17 \text { Kendaraan } \\
\text { Bermotor milik siswa terbakar } \\
\text { habis, dan } 17 \text { lainnya terbakar } \\
\text { sebagian. }\end{array}$ \\
\hline & & $\begin{array}{l}\text { SMKN } \\
1\end{array}$ & 55 Motor Hangus \\
\hline \multirow{3}{*}{2019} & SMP & $\begin{array}{l}\text { SMPN } \\
32\end{array}$ & $\begin{array}{l}\text { Sebagian ruang laboratorium } \\
\text { dan instalasi listrik terbakar, }\end{array}$ \\
\hline & SMA & $\begin{array}{l}\text { SMA } \\
\text { GIKI } 1\end{array}$ & $\begin{array}{l}\text { Memicu kepanikan pihak } \\
\text { sekolah. }\end{array}$ \\
\hline & SMK & $\begin{array}{l}\text { SMKN } \\
2\end{array}$ & $\begin{array}{l}3 \text { Mobil bekas milik sekolah } \\
\text { hangus terbakar, atap ruang } \\
\text { kelas terbakar } 10 \% \text {, seorang } \\
\text { siswa luka ringan }\end{array}$ \\
\hline 2020 & SD & $\begin{array}{l}\text { SDN } \\
\text { Kutisari } \\
\text { II }\end{array}$ & $\begin{array}{l}\text { Kursi dan Meja untuk kelas } \\
\text { Rusak }\end{array}$ \\
\hline
\end{tabular}

Sumber Data : (Fauzi, 2017), (Rinanda, 2018), (Sukowati, 2018), (Romadoni, 2018), (Mahendro, 2018), (Hidayat, 2019), (Pambudi, 2019), (Tito \& Bakrie, 2019), (Nurhartanto, 2018) 
Berdasarkan tabel 1, kebakaran di Surabaya terjadi hampir di semua jenjang Institusi Pendidikan sehingga menimbulkan korban jiwa dan kerusakan.

Tabel 2. Data Korban Jiwa Akibat kebakaran

\begin{tabular}{|c|c|}
\hline Tahun & Jumlah Korban \\
\hline $\mathbf{2 0 1 6}$ & 3 \\
\hline $\mathbf{2 0 1 7}$ & 367 \\
\hline $\mathbf{2 0 1 8}$ & 8 \\
\hline $\mathbf{2 0 1 9}$ & 13 \\
\hline $\mathbf{2 0 2 0}$ & 4 \\
\hline $\mathbf{2 0 2 1}$ & 7 \\
\hline
\end{tabular}

Sumber Data : (BNPB, 2021)

Tabel 2 menunjukkan jumlah korban yang ditimbulkan akibat kebakaran. Berdasarkan tabel 1 dan 2 dapat disimpulkan bahwa, tingginya potensi bencana kebakaran berpengaruh terhadap jumlah korban terutama anak-anak.

Dikutip dari Pusat Krisis Kesehatan (Kesehatan, 2018), terjadi kebakaran alang-alang di sekitar Pondok Benowo Indah, Surabaya Barat. Hal tersebut menunjukkan, di wilayah Surabaya Barat berpotensi mengalami kebakaran termasuk institusi pendidikan di wilayah tersebut.

SD AlKautsar merupakan salah satu sekolah dasar swasta yang berlokasi di Perumahan Pondok Benowo Indah. Kawasan tersebut merupakan pemukiman padat penduduk yang berpotensi terjadinya kebakaran. Hal tersebut mendorong tim melakukan observasi dan wawancara terkait kesiapsiagaan bencana kebakaran pada siswa di SD AlKautsar. Berdasarkan hasil observasi dan wawancara yang dilakukan tim didapatkan hasil seperti gambar 1 berikut.

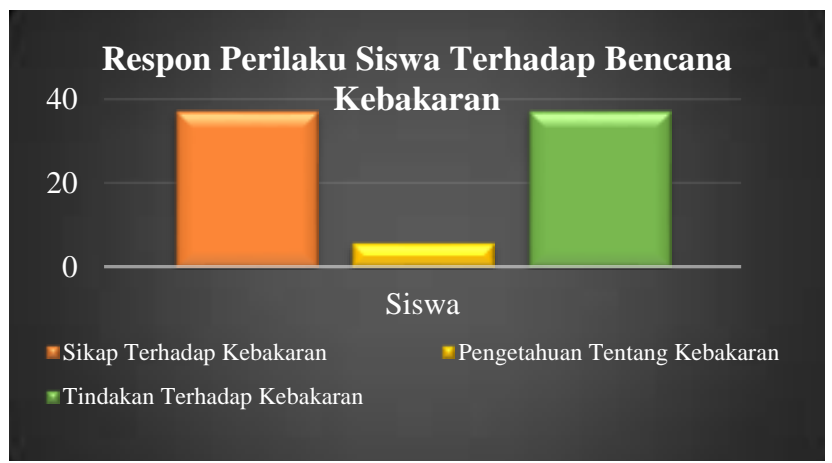

Gambar 1. Hasil Observasi dan Wawancara yang dilakukan tim.
Sumber Data : Wawancara dengan warga sekolah SD AlKautsar (2019)

Gambar 1 menunjukkan bahwa persepsi siswa khususnya siswa kelas $5 \mathrm{SD}$, mengenai sikap dan tindakan terhadap bencana kebakaran yakni pada kategori baik, namun pengetahuan siswa tentang kebakaran pada kategori sedang. Dengan demikian, dapat disimpulkan bahwa persepsi siswa tentang kebakaran tidak diimbangi dengan pengetahuan, sehingga berdampak pada kurangnya sikap kesiapsiagaan bencana kebakaran yang dimiliki oleh siswa.

Berdasarkan data permasalahan tersebut dan tingginya potensi terjadi kebakaran serta ancaman akibat kebakaran terhadap anak-anak di wilayah tersebut, mendorong dilaksanakannya mitigasi bencana kebakaran, kesiapsiagaan menghadapi bencana kebakaran dan pengurangan risiko bencana perlu ditingkatkan. Upaya tersebut diwujudkan melalui kegiatan Pengabdian Kepada Masyarakat berupa peningkatan softskill terhadap mitigasi dan kesiapsiagaan bencana kebakaran kepada anak sejak usia dini yang dilaksanakan di SD AlKautsar Surabaya bagi kelas V.

\section{METODE}

Kegiatan pengembangan softskill tanggap bencana kebakaran sebagai upaya preventif bagi siswa SD dilaksanakan dengan metode Hybrid Learning yaitu kombinasi antara luring dan daring melalui tahapan sebagai berikut.

\section{a. Observasi}

Tim melakukan observasi untuk mengidentifikasi persepsi sikap, pengetahuan dan tindakan siswa tentang bencana kebakaran yang dimiliki oleh siswa di SD AlKautsar. Observasi dilakukan pada siswa kelas 5 SD AlKautsar Surabaya. Dalam observasi tersebut, Tim melakukan penyebaran kuisioner guna mengetahui kategori sikap, pengetahuan dan tindakan siswa di SD AlKautsar Surabaya.

Tim memilih siswa kelas 5 SD yang berusia 10-12 tahun sebagai sasaran program karena pada rentang usia tersebut anak memiliki daya ingat yang 
maksimal. (Kartono, 2003) mengungkapkan ingatan anak pada usia tersebut mencapai intensitas paling besar dan paling kuat daya menghafal dan daya memorisasi sehingga anak mampu memuat materi ingatan paling banyak. Kelas 5 juga dinilai cukup mengerti situasi di sekolah dan mampu melakukan transfer ilmu terkait program yang akan diterapkan ke kelas atau tingkat dibawahnya dan masih belum mendapatkan tekanan untuk fokus persiapan Ujian Nasional seperti halnya siswa kelas 6 .

b. Sosialisasi secara luring dengan prokes

Sosialisasi kepada pihak manajemen sekolah dan wali kelas siswa kelas 5 dilaksanakan secara luring dengan memperhatikan protokol kesehatan. Tim melakukan sosialisasi untuk memperkenalkan program pendampingan kesiapsiagaan bencana yang akan dilaksanakan dengan sasaran siswa kelas 5 SD.
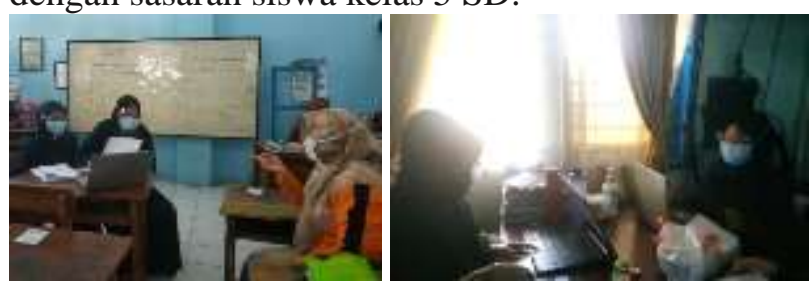

Gambar 2. Sosialisasi tim kepada Manajemen Sekolah

Sosialisasi berisikan tentang pelaksanaan program pengembangan softskill mitigasi dan kesiapsiagaan bencana kebakaran oleh tim, dilanjutkan sesi diskusi terkait teknis pelaksanaan program melalui koordinasi dengan pihak sekolah yang melibatkan wali kelas. Sosialisasi tentang program pengembangan softskill mitigasi dan kesiapsiagaan bencana kebakaran ke wali murid dilaksanakan oleh wali kelas selaku pihak sekolah.

\section{c. Pendampingan Via Daring (Dalam Jaringan)}

Pelaksanaan program pengabdian kepada masyarakat berupa pengembangan soft skill mitigasi dan kesiapsiagaan bencana kebakaran dilaksanakan melalui pendampingan secara daring. Hal tersebut dikarenakan kondisi pandemi memberikan dampak pada pendidikan di Indonesia. Untuk menekan jalur penyebaran COVID-19, KEMDIKBUD mengeluarkan Surat Edaran Nomor 4 Tahun 2020 tentang Pelaksanaan kebijakan Pendidikan dalam Masa Darurat Penyebaran Coronavirus Disease
(COVID-19). Dalam surat edaran tersebut dimaksudkan bahwa pendidikan di Indonesia dilaksanakan secara daring. Berdasarkan kebijakan tersebut sistem pengajaran di SD AlKautsar menggunakan sistem daring sehingga tim mendapatkan arahan dari pihak sekolah untuk menggunakan metode yang sama dalam memberikan pendampingan kepada siswa.

Pendampingan pengembangan softskill dilakukan sebanyak 5 kali TM (Tatap Muka), masing-masing berdurasi 60 menit dengan materi yang berbeda, dilakukan secara daring dengan memanfaatkan platform teleconference google meet dan mentimeter untuk kuis. Penggunaan aplikasi teleconference jenis google meet menyesuaikan kesepakatan antara pihak manajamen sekolah dengan komite sekolah dengan mempertimbangkan penggunaan kuota.

Dengan demikian guru dan siswa menggunakan aplikasi teleconference jenis google meet dalam aktivitas pembelajaran sehari-hari. Maka tim pengabdian menyesuaikan penggunaan aplikasi teleconference jenis google meet untuk pelaksanaan program pendampingan dan pemberdayaan siswa SD AlKautsar terkait pengembangan softskill mitigasi dan kesiapsiagaan bencana kebakaran.

\section{d. Pembentukan Komunitas}

Setelah mengikuti tahap pendampingan secara daring, tim merancang pembentukan komunitas serta melaksanakan penyusunan buku panduan guna menjaga keberlanjutan program. Berikut merupakan rancangan struktur organisasi komunitas di SD AlKautsar.

\section{RANCANGAN STRUKTUR ORGANISASI FIRE FIGHTER}

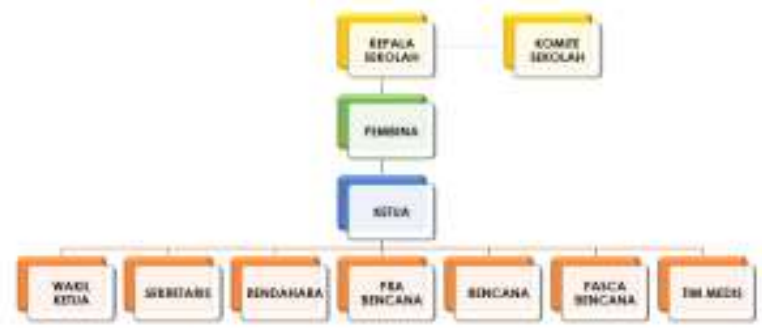


Gambar 3. Rancangan Struktur Organisasi Fire Fighter

\section{HASIL DAN PEMBAHASAN}

\section{Observasi}

Observasi dilaksanakan dengan membagikan kuisioner yang bertujuan untuk mengetahui persepsi siswa kelas $\mathrm{V}$ terkait sikap, pengetahuan dan tindakan kesiapsiagaan bencana kebakaran. Berdasarkan hasil observasi yang telah telakukan oleh tim, disimpulkan bahwa tingkat kesiapsiagaan bencana kebakaran pada siswa SD AlKautsar dalam kategori rendah. Hal tersebut dikarenakan, persepsi sikap dan tindakan siswa SD AlKautsar tentang kebakaran dalam kategori baik namun tidak diiringi dengan persepsi pengetahuan tentang kebakaran.

Dengan demikian maka diperlukan tahapan lebih lanjut untuk meningkatkan softskill terhadap mitigasi dan kesiapsiagaan bencana kebakaran pada siswa di SD AlKautsar. Tahapan tersebut dilaksanakan melalui program pengabdian kepada masyarakat pengembangan softskill mitigasi dan kesiapsiagaan bencana kebakaran dengan sasaran siswa kelas V SD AlKautsar Surabaya.

\section{Sosialisasi secara luring dengan prokes}

Sosialisasi dilaksanakan oleh tim kepada manajemen sekolah yang diwakili oleh Kepala Sekolah Wali Kelas VA dan Wali Kelas VB secara luring dengan tetap memperhatikan protokol kesehatan.

Pihak yang mewakili manajemen sekolah menyetujui pelaksanaan program peningkatan softskill mitigasi dan kesiapsiagaan bencana kebakaran yang akan diimplementasikan di SD AlKautsar Surabaya, dengan catatan model pendampingan dilaksanakan secara daring (dalam jaringan) melalui aplikasi teleconference jenis google meet, berdurasi tidak lebih dari 1 jam dengan jadwal sesuai dengan arahan dari pihak wali kelas lima. Hasil dari sosialisasi berupa kesepakatan jadwal pelaksanaan pendampingan dan juga hasil koordinasi dengan wali kelas lima untuk menjadi perantara dalam memberikan informasi program yang dilakukan oleh tim kepada wali murid siswa kelas 5 .

Berikut merupakan jadwal pelaksanaan pendampingan.

Tabel 3. Jadwal Pelaksanaan Pendampingan SD AlKautsar Surabaya

\begin{tabular}{|c|l|c|c|}
\hline TM & Hari/Tgl & Pukul & Peserta \\
\hline Ke-1 & Rabu & $12.30-13.30$ & VA \\
\hline & Jum'at & $12.30-13.30$ & VB \\
\hline Ke-2 & Jum'at & $12.30-13.30$ & VA \\
\hline & Kamis & $12.30-13.30$ & VB \\
\hline Ke-3 & Kamis & $12.30-13.30$ & VA \\
\hline & Jum'at & $12.30-13.30$ & VB \\
\hline Ke-4 & Kamis & $12.30-13.30$ & VA \\
\hline & Jum'at & $12.30-13.30$ & VB \\
\hline Ke-5 & Sabtu & $12.30-13.30$ & VA dan VB \\
\hline
\end{tabular}

Sumber : Data diolah (2020)

Berdasarkan tabel 3 tersebut, dapat dilihat bahwa pendampingan untuk masing-masing kelas dilaksanakan 1 minggu 1 kali, dalam jangka pekan yang berurutan. Hal tersebut bertujuan untuk memudahkan siswa dalam memahami, mengetahui dan menerapkan materi ajar tentang siaga kebakaran yang disampaikan, selaras dengan (Latifah, 2021) yang menyatakan proses memahami siswa dimulai dari pembelajaran yang diulangulang.

\section{Pendampingan pembelajaran secara daring}

Tahap pendampingan pembelajaran dilaksanakan sebanyak 5 kali pertemuan pada masing-masing kelas secara daring. Berikut merupakan susunan materi yang disampaikan pada masing-masing pertemuan.

Tabel 4. Tahapan Pelaksanaan Pendampingan Pembelajaran

\begin{tabular}{|l|ll|}
\hline TM & \multicolumn{1}{c|}{ Jenis Kegiatan } \\
\hline Ke-1 & - & Pretest : Google Form \\
& - & Materi I : Kesiapsiagaan Bencana \\
& - & Kuis : Mentimeter \\
\hline Ke-2 & - & Materi II : Bencana Kebakaran \\
& - & Kuis : Mentimeter \\
\hline Ke-3 & - & Materi III : Damkar dan Apar \\
& - & Kuis : Mentimeter \\
\hline Ke-4 & - & Materi IV : Pertolongan Pertama pada luka \\
& & bakar \\
& - & Kuis : Mentimeter \\
\hline
\end{tabular}


\begin{tabular}{|l|ll}
\hline Ke-5 & - & Materi V : Mari Siaga Kebakaran
\end{tabular} Posttest : Google Form

Berdasarkan tabel 4 tersebut pada proses pendampingan terdiri dari kegiatan : 1) Pemberian Pretest diawal pertemuan, 2) pendampingan pembelajaran dengan memberikan materi tentang bencana kebakaran dan kuis yang dilaksanakan disetiap pertemuan dan 3) Post Test diakhir pertemuan setelah siswa mendapatkan seluruh materi yang diberikan.

\section{a. Pretest}

Pretest bertujuan untuk mengukur pengetahuan siswa sebelum dilaksanakan pendampingan terkait peningkatan softskill mitigasi bencana kebakaran. Pretest dilaksanakan secara online dengan memanfaatkan platform google form.
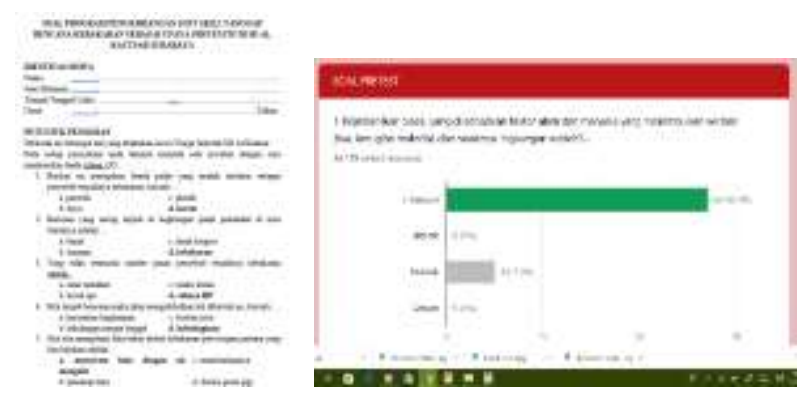

Gambar 4. Soal pretest dan Pengisian Pretest

Rata-rata nilai pretest siswa SD AlKautsar Surabaya sebesar 63,45 (setara 2,35 dalam skala 4) dengan nilai tersebut pengetahuan siswa SD AlKautsar masuk dalam kategori $\mathrm{C}+$. Nilai tersebut selaras dengan hasil observasi yang menunjukkan rendahnya persepsi pengetahuan siswa mengenai mitigasi dan kesiapsiagaan bencana kebakaran. Maka perlu dilaksanakan pendampingan untuk meningkatkan pengetahuan softskill mitigasi dan kesiapsiagaan bencana kebakaran pada siswa kelas V SD AlKautsar.

\section{b. Pelaksanaan Pendampingan Pembelajaran}

Pendampingan program peningkatan softskill mitigasi dan kesiapsiagaan bencana kebakaran bagi siswa SD AlKautsar dilaksanakan secara online synchronous learning dengan aplikasi google meet dan asynchronous learning melalui video animasi yang disusun oleh tim dan diunggah ke aplikasi youtube.

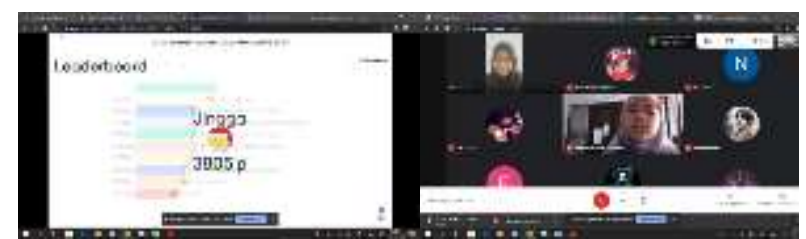

Gambar 5. Pendampingan secara daring via google meet

Pada tahap pendampingan yang dilakukan secara daring, tim memberikan materi sesuai dengan rangkaian materi dengan menggunakan media buku saku sebagai dasar materi, video animasi untuk memudahkan siswa menerima materi secara audio visual dan kuis dengan menggunakan apliasi mentimeter diakhir sesi untuk mengukur pemahaman siswa terhadap materi yang telah disampaikan. Video animasi disusun menggunakan software Microsoft powerpoint dan adobe premiere. Video animasi disusun untuk semua materi dengan judul dan garis besar yang berbeda serta dibuat secara berurut dan terstruktur.
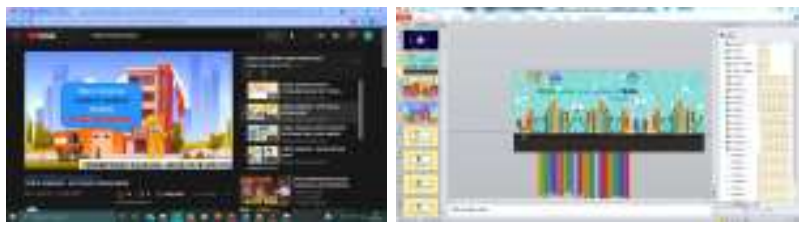

Gambar 6. Penyusunan video animasi ke youtube

Pada tahap pendampingan, tim juga melaksanakan penyusunan buku saku dan dibagikan kepada siswa berupa e-book (pdf) untuk mendukung pendampingan secara asynchronous learning.

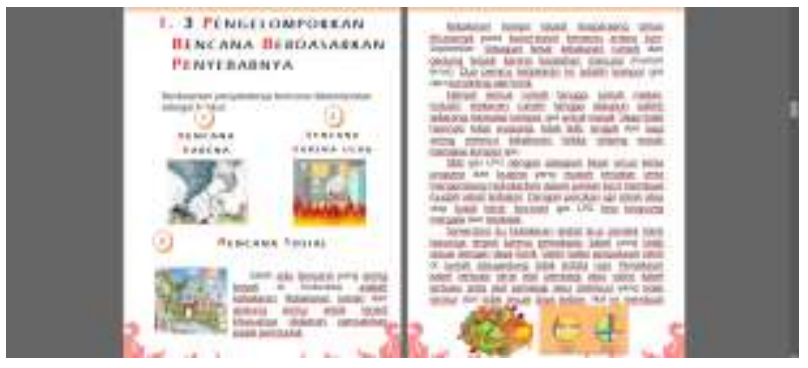

Gambar 7. Penyusunan Buku Saku Ayo Siaga Kebakaran 
Pola pendampingan tersebut dirancang agar mampu meningkatkan self-efficacy siswa terhadap sikap dan tindakan siaga kebakaran. Self-efficacy didefinisikan sebagai kemampuan yang dirasakan untuk melakukan suatu perilaku yang secara kausal atau sebab akibat mempengaruhi hasil yang diharapkan dari perilaku, tetapi tidak sebaliknya (Williams, 2010). Hasil yang diharapkan dari perilaku tersebut adalah soft skill tanggap bencana terhadap kebakaran.

Karakteristik kunci dari self-efficacy adalah komponen skill (keahlian) dan ability (kemampuan) dalam mengorganisir dan melaksanakan suatu tindakan (Jum'ati \& Setyowati, 2015). Ada empat unsur informasi yang mempengaruhi self-efficacy pada masing-masing individu (Jum'ati \& Setyowati, 2015), yaitu : 1) guided mastery, merupakan pengalaman keberhasilan yang berkaitan dengan perilaku. Kesuksesan interaksi antara siswa dengan upaya siaga bencana mengembangkan selfefficacynya lebih tinggi; 2) behaviour modelling, permodelan yang meliputi pengamatan terhadap orang lain dalam membentuk perilaku sebagai proses pembelajaran; 3) social persuasion, pendekatan secara persuasif juga dapat mempengaruhi self-efficacy. Keberhasilan menciptakan suasanya yang menyenangkan menjadi salah satu pendekatan secara persuasif sehingga berdampak terhadap self-efficacy pada diri siswa; 4) physiologi States, yang menunjukkan perasaan kecemasan atau anxiety yang berdampak negative terhadap self-efficacy.

\section{c. Posttest}

Pada akhir tahap pendampingan, dilaksanakan posttest untuk mengukur perubahan pengetahuan yang dimiliki oleh siswa di SD AlKautsar Surabaya. Posttest dilaksanakan secara online dengan google form.

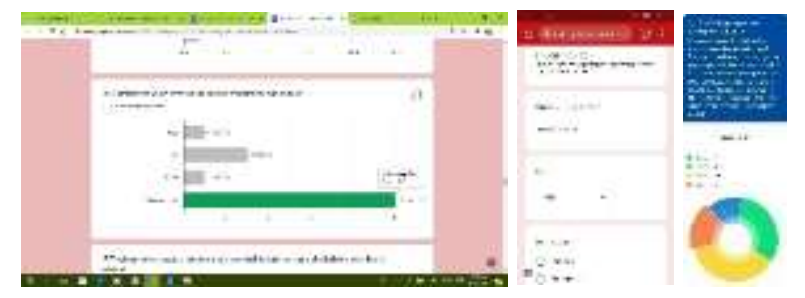

Gambar 8. Pengisian Posttest oleh siswa

Tim melakukan pengukuran perubahan pengetahuan siswa sebelum dan sesudah adanya program berdasarkan nilai mean pada pretest dan posttest.

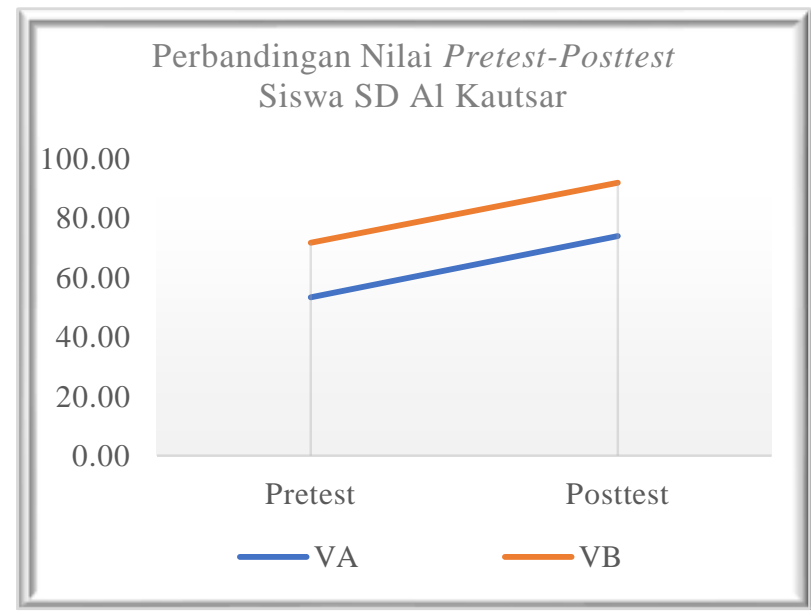

Gambar 9. Grafik perubahan nilai pretest-posttest siswa SD AlKautsar

Berdasarkan gambar 9, disimpulkan bahwa, terjadi perubahan pengetahuan tentang kebakaran pada siswa di SD AlKautsar. Perubahan pengetahuan turut meningkatkan kemampuan softskill mitigasi dan kesiapsiagaan bencana kebakaran. Dengan meningkatnya kemampuan (ability) pengetahuan mengenai softskill, akan mendorong tingkat kepercayaan diri siswa dalam mengimplementasikan tindakan sehingga turut mempengaruhi meningkatnya self-efficacy pada siswa (Jum'ati \& Setyowati, 2015).

Peningkatan self-efficacy pada siswa sehingga siswa dapat menjadi peer leadership guna melanjutkan transfer ilmu kepada lingkungan disekitarnya. Siswa yang memiliki self-efficacy tinggi maka akan mempunyai memiliki tingkat komitmen yang lebih tinggi untuk menyelesaikan tugas dan bertahan dengan tugas (Anonim, 2018).

\section{Pembentukan Komunitas}

Pembentukan komunitas bertujuan untuk menjaga keberlanjutan program peningkatan 
softskill mitigasi dan kesiapsiagaan bencana kebakaran.

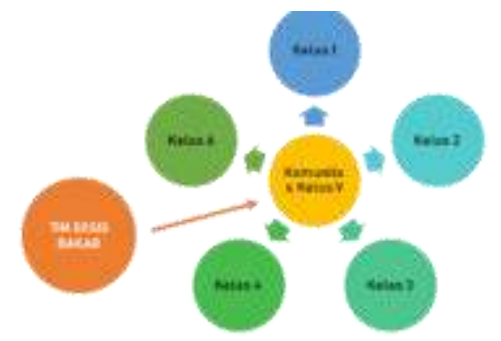

Gambar 10. Proses pembentukan komunitas fire fighter dan transfer ilmu untuk menjaga keberlanjutan program

Untuk mendukung pembentukan komunitas sebagai upaya keberlanjutan program, tim melakukan penyusunan dan pengunggahan video animasi ke channel youtube sebagai salah satu bahan ajar dalam melaksanakan program (https://www.youtube.com/channel/UCmMIfjLOfK s5EGufcBEXc6w)

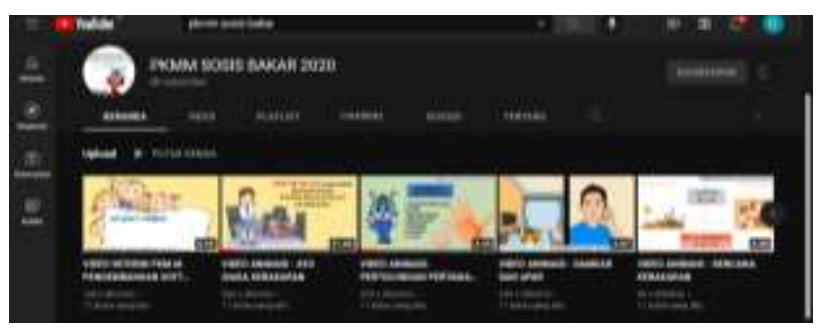

Gambar 10. Channel Youtube untuk Video Animasi penunjang keberlanjutan program

Video animasi sebagai bahan ajar secara audio dan visual yang diunggah ke channel youtube diperkuat dengan bahan ajar lainnya berupa $e$-book sebagai buku saku pegangan bagi siswa.

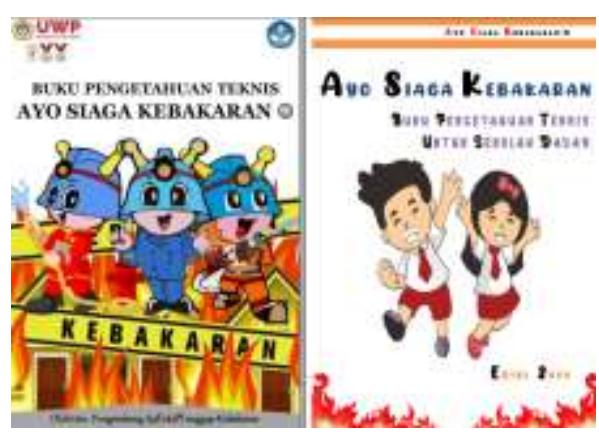

Gambar 11. E-Book Buku Saku Siaga Kebakaran
Tim melakukan penyusunan buku panduan pelaksanaan program yang berfungsi sebagai pedoman pelaksanaan program bagi manajemen sekolah, sehingga program pengembangan softskill akan terus berkelanjutan dan memberikan manfaat bagi lingkungan sekitarnya.

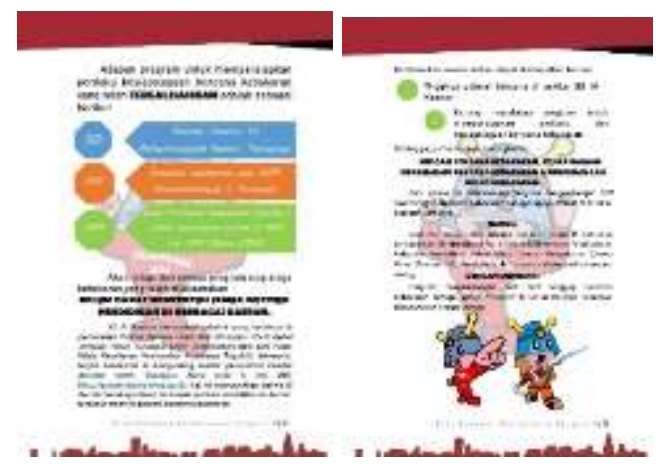

Gambar 12. Buku panduan pelaksanaan program

Serangkaian upaya keberlanjutan program tersebut juga didukung dengan adanya peningkatan kemampuan self-efficacy atau kepercayaan diri siswa dalam melakukan tindakan terkait softskill mitigasi dan kesiapsiagaan bencana. Meningkatnya self-efficacy dalam diri siswa juga mendorong terciptanya lingkungan SD AlKautsar dan sekitarnya sebagai lingkungan yang siap siaga menghadapi kebakaran.

Pembentukan komunitas diserahkan sepenuhnya kepada pihak manajemen sekolah SD AlKautsar karena pembentukan tersebut memerlukan kesepakatan dengan komite sekolah SD AlKautsar.

\section{Berita di Koran Radar online}

Keseluruhan rangkaian aktivitas dan hasil dari pengabdian soft skill tanggap bencana terhadap kebakaran dipublikasikan di Radar Surabaya secara online dengan link url https://today.line.me/id/v2/article/aRL293. 


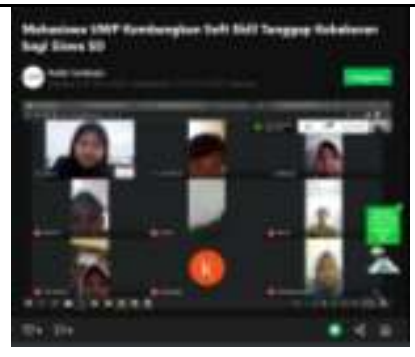

Gambar 13. Berita di Koran Radar Online

Dengan publikasi di koran online bertaraf regional dan area Surabaya maka diharapkan masyarakat umum mengetahui adanya aktivitas pengembangan softskill mitigasi dan kesiapsiagaan bencana pada anak sejak dini dengan sasaran siswa kelas V SD AlKautsar sehingga dapat meningkatkan kesadaran (awareness) masyarakat terkait pentingnya program kesiapsiagaan bencana.

\section{KESIMPULAN}

Kegiatan pengabdian kepada masyarakat berupa peningkatan softskill mitigasi dan kesiapsiagaan bencana kebakaran bagi siswa SD memberikan perubahan kemampuan (agibility) pengetahuan dan softskill yang diiringi dengan perubahan self-efficacy pada diri siswa. Hal tersebut selaras dengan Luthans dalam (Jum'ati \& Setyowati, 2015), selain itu self-efficacy dipengaruhi oleh 4 informasi yaitu : (1) Guided mastery, (2) Behaviour modelling, (3) Social persuasion, dan (4) Physiologi states, 4 faktor tersebut dikemas dalam program peningkatan softskill yang dilakukan. Teori self-efficacy didasarkan pada keyakinan individu terhadap yang benar secara objektif (Ashfaq \& Abid, 2021) sehingga dengan bekal pengetahuan yang dimiliki, siswa memiliki sebuah dorongan untuk mengimplementasikan atau melakukan sebuah tindakan yang menurutnya benar secara objektif. Tingginya self-efficacy mitigasi dan kesiapsiagaan bencana kebakaran pada siswa mendorong meningkatnya komitmen siswa untuk tetap bertahan dan menyelesaikan tugasnya.

Dengan hal tersebut, maka siswa mampu menjadi peer leadership yang berperan sebagai agent of change untuk melakukan transfer ilmu kepada lingkungan sekitarnya terkait softskill mitigasi kesiapsiagaan bencana kebakaran. Siswa juga dapat melakukan Tindakan yang tepat dan benar apabila terjadi bencana beserta pertolongan pertama yang dibutuhkan apabila ada luka pada saat bencana terjadi.

Saran yang dapat diberikan oleh tim adalah adanya keberlanjutan program melalui pembentukan komunitas menjadi hal yang harus ditekankan untuk menjaga proses transfer of knowledge sehingga terbentuk lingkungan SD AlKautsar yang memiliki kesiapsiagaan terhadap bencana kebakaran. Dengan demikian, diharapkan manajemen sekolah, komiete sekolah dan guru sebagai pembimbing yang berperan untuk pembentukan dan pemeliharaan komunitas.

\section{UCAPAN TERIMAKASIH}

Terimakasih kami ucapkan kepada KEMDIKBUD yang telah mendukung pelaksanaan program melalui PKM-M (Program Kreativitas Mahasiswa- Pengabdian Kepada Masyarakat). Terimkasih juga kami sampaikan kepada Universitas Wijaya Putra dan SD AlKautsar yang menjadi wadah bagi pelaksanaan program.

\section{REFERENSI}

Anonim. (2018). The Importance Of Self-Efficacy. OVP Management Consulting Group Inc. https://www.ovpconsulting.com/weekly/2018/ 11/16/086p3teoj8d0dbvuwbt51sh7qkc63c

Ashfaq, F., \& Abid, G. (2021). Impact of Ethical Leadership on Employee Engagement: Role of Self-Efficacy and Organizational Commitment. European Journal of Investigation in Health, Psychology and Education, 11, 962-974.

Badan Pusat Statistik. (2021). Statistik Indonesia (D. D. Statistik (ed.); Edisi Kesa, p. 804). Badan Pusat Statistik.

BNPB. (2017). Potensi Ancaman Bencana. BNPB. https://bnpb.go.id/potensi-ancaman-bencana

BNPB. (2021a). Definisi Bencana. BNPB. https://www.bnpb.go.id/definisi-bencana 
BNPB. (2021b). Geoportal Data Bencana Indonesia. BNPB. https://gis.bnpb.go.id/

Fauzi, P. (2017). Kebakaran di SDN Kapasan 3 Surabaya, Begini Kata Kepala Sekolah. Tribunjatim.Com.

Hidayat, W. (2019). SMPN 32 Surabaya Terbakar. Infosurabaya.Id.

https://infosurabaya.id/2019/03/05/smpn-32surabaya-terbakar/

Jum'ati, N., \& Setyowati, Y. (2015). Analisis Faktor-Faktor Model Perilaku Big Five (Extraversion, Agreeableness, Conscientiousness, Neurotisicm, Opennes To Experience) terhadap Computer Self Efficacy dan Kepuasan Kerja Guru (Studi Kasus di SMA-SMK Wijaya Putra Surabaya). Ekonomi'45 Jurnal Ilmiah Manajemen Dan Akuntansi, 3(1), 7-8.

Kartono, K. (2003). Patologi Sosial 3 : Gangguangangguan Kejiwaan (Edisi 2 Ce). PT. RajaGrafindo Persada.

Kesehatan, P. K. (2018). Kebakaran Alang-Alang di Benowo. Badan Pusat Krisis Kesehatan.

Latifah, N. (2021). Pembelajaran Al Qur' an Pada Program Tahfidz Balita dan Anak Usia Dini. Journal Of Instructional and Development Researches, 1(1), 41-47.

Mahendro, A. (2018). Parkiran Dekat SMKN 1 Surabaya Terbakar, 55 Motor Hangus. Jawapos.Com. https://www.jawapos.com/jpgtoday/18/10/2018/parkiran-dekat-smkn-1surabaya-terbakar-55-motor-hangus/

Nurhartanto, S. (2018). Tumpukan Barang di Halaman SDN Kutisari II Surabaya Terbakar. Jatimnow.Com. https://jatimnow.com/baca30493-tumpukan-barang-di-halaman-sdnkutisari-ii-surabaya-terbakar

Pambudi, L. (2019). Kebakaran Warung Kpi Picu Kepanikan Siswa GIKI 1 Surabaya, Siswa TK hingga SMA Pulang Lebih Awal. Jatim.Tribunnews.Com. https://jatim.tribunnews.com/2019/09/23/keba karan-warung-kopi-picu-kepanikan-siswagiki-1-surabaya-siswa-tk-hingga-sma-pulanglebih-awal.

Rinanda. (2018). Kebakaran SMPN 21 Surabaya, Siswa Panik Berhamburan Keluar. News.Detik.Com. https://news.detik.com/berita-jawa-timur/d4152091/kebakaran-smpn-21-surabaya-siswapanik-berhamburan-keluar?

Romadoni, M. (2018). Romadoni, Mohammad. Surabaya.Tribunnews.

https://surabaya.tribunnews.com/2018/09/26/t erbakarnya-18-sepeda-motor-siswa-smkn-6surabaya-tim-inafis-polrestabes-surabayalakukan-olah-tkp.

Samodro, D. (2020). BNPB katakan 31 persen korban bencana 2020 adalah anak-anak. Antaranews.

https://www.antaranews.com/berita/1326110/b npb-katakan-31-persen-korban-bencana-2020adalah-anak-anak

Sukowati, P. (2018). Kebakaran Hanguskan Gudang di SMPN 42 Surabaya, Seorang Siswa Cedera. Kumparan.Com. https://kumparan.com/kumparannews/kebakar an-hanguskan-gudang-di-smpn-42-surabayaseorang-siswa-cedera-1536913600307983096.

Tito, F., \& Bakrie, N. (2019). Sampah di SMKN 2 Surabaya Terbakar, 3 Mobil Bekas Hangus Terbakar. Kumparan.Com. https://jatimnow.com/baca-21702-sampah-dismkn-2-surabaya-terbakar-3-mobil-bekashangus-tersambar

Williams, D. M. (2010). Outcome expectancy and self-efficacy: Theoretical implications of an unresolved contradiction. Personality and Social Psychology Review, 14(4), 417-425. https://doi.org/10.1177/1088868310368802 